\title{
Teaching Reading Online for a Small Class: an Instructional Design for Teaching Reading Online
}

\author{
Yopi Arianto \\ Kahuripan University of Kediri, Jl. Soekarno Hatta 1 Pelem, Pare, Kediri \\ Yopiarianto81@gmail.com
}

\begin{abstract}
The digital technology has equipped people especially the students with applications needed for online learning in the form of applications. However, these applications will be useless if the online learning concept is not applied in the correct way. This research is aimed to describe qualitatively the instructional design of teaching reading online in a small class which consists of 5 students. The method of the research is qualitative research. The data collected by observing the process of learning, documenting, and reflecting the process. The results found that the small numbers of students is the most important aspect to make the instructional design effective. All the students were active in the online learning. The online media used were Google Meet and WhatApps Group (WAG). The Google Meet was the substitution of classroom sessions and WAG was the medium to sending the materials. The effective instructional design is shown from the progress test scores -the highest score for the progress test was 92 and the lowest was 78. The score indicates that small class is effective in encouraging students' participation, hence the instructional design is effective.
\end{abstract}

Keywords: teaching Reading, instructional design, small class

\section{Introduction}

Pandemic of Covid-19 has changed many aspects of life including teaching English. The students now have to get use to with new way of learning applied by the teacher. It is online learning. Fortunately, the digital technology has equipped people especially the students with applications needed for online learning as follows: chatting application like WhatApps, video conference like Zoom and Google Meet, 
blended learning application like Google Classroom, Edmodo, or Zenius Education. The teachers' job is to maximize these applications with proper online learning concept. She or he must plan and execute it to make the students find that online learning is as effective as face to face learning. One of the credit points from the students is they are already get use to with the gadget and the process of adaptation with the blended learning application will not take much time.

The teacher and students are in the moment of adaptation with the new way of teaching and learning. The teacher may in the phase of trial and error where all the methods are tried until the students feel comfortable with the teaching and learning process. However, the teacher or the students may be in the point where the online learning is just a new meaningless habit. The point is the negative effect of pandemic and the teacher must be ready for it. The planned instructional design of online learning must be arranged in different way from traditional class. Drake et.al (1996) argued that Instructional design is a technology for the development of learning experiences and environments which promote the acquisition of specific knowledge and skill by students.

Teaching online for a small class with 5 students seems easy. This argument is not wrong but for the teacher must understand each student's learning style. Some from five's learning style may not get comfortable with the online learning. For example, the auditory students may not find the difficulty in joining online learning 
but the visual learner may need more time to adapt with the process. So, the small class may give a clear picture of how online learning applied in the bigger class with more than 15 students. In other side, the number of students allows the teacher to do "surveillance" easier. However, the teacher needs to develop instructions to assure that the students understand the context of the text no matter what are their learning styles. The five students surely have to follow the instructions from the beginning to the end of every meeting.

\section{Literature Review}

\section{Teaching Online}

E-learning, also referred to as online learning or electronic learning, is the acquisition of knowledge which takes place through electronic technologies and media (Tamm, 2019) . Typically, e-learning is conducted on the Internet, where students can access their learning materials online at any place and time. E-Learning most often takes place in the form of online courses, online degrees, or online programs.

The online learning actually has been applied from years ago and it has been proven as an efficient and effective in cost. The e-learning could break the space and it is a benefit for the students who has problem with distance. However, the advantages of the e-learning are more than just a space break. Based on Clover (2017), the followings are the advantages of e-learning: 
1. You are able to link the various resources in several varying formats.

2. It is a very efficient way of delivering courses online.

3. Due to its convenience and flexibility, the resources are available from anywhere and at any time.

4. Everyone, who are part time students or are working full time, can take advantage of web-based learning.

5. Web-based learning promotes active and independent learning.

6. As you have access to the net $24 \times 7$, you can train yourself anytime and from anywhere also.

7. It is a very convenient and flexible option; above all, you don't have to depend on anyone for anything.

8. Not only can you train yourself on a day to day basis, but also on weekends or whenever you have the free time to. There is no hard and fast rule.

9. Through discussion boards and chats, you are able to interact with everyone online and also clear your doubts if any.

10.The video instructions that are provided for audio and video learning can be rewound and seen and heard again and again if you do not happen to understand the topic first time around.

The advantages of e-learning are many and could help the students to get the new knowledge or skill. For short, e-learning offer the flexibility that the traditional 
class doesn't. But the teacher must consider the disadvantages before she/he runs an e-learning class as the step of anticipation. Tamm (2019) also describes the disadvantages of e-learning as the followings:

1. Most of the online assessments are limited to questions that are only objective in nature.

2. There is also the problem of the extent of security of online learning programs.

3. The authenticity of a particular student's work is also a problem as online just about anyone can do a project rather than the actual student itself.

4. The assessments that are computer marked generally have a tendency of being only knowledge-based and not necessarily practicality-based.

The online learning is like the traditional teaching method. It has advantages and the disadvantages. The teacher must understand how to maximize e-learning and get the advantages. These advantages could be a consideration in planning an instructional design while the disadvantages are the things to anticipate. The teacher must play the same role as the traditional class, she or he could be a planner, leader and the evaluator but with IT skill. 


\section{The Types of Online Learning}

The online learning or e-learning has been started since a long ago and has been developed time to time since then. The development is directed by the effectiveness and efficiency of the methods and the teaching learning process. The followings are the types of online learning based on the point of views of Sener (2015):

1. Classroom Course - Course activity is organized around scheduled class meetings.

2. Synchronous Distributed Course-Web-based technologies are used to extend classroom lectures and other activities to students at remote sites in real time.

3. Web-Enhanced Course - Online course activity complements class sessions without reducing the number of required class meetings.

4. Blended (also called Hybrid) Classroom Course - Online activity is mixed with classroom meetings, replacing a significant percentage, but not all required face-to-face instructional activities.

5. Blended (also called Hybrid) Online Course - Most course activity is done online, but there are some required face-to-face instructional activities, such as lectures, discussions, labs, or other in-person learning activities. 
6. Online Course - All course activity is done online; there are no required face-to-face sessions within the course and no requirements for oncampus activity.

The online class done in this research is the classroom course. The teacher and the students never did the face to face class. All the materials are shared in the WhatApps group (WAG) and all the meeting are done via Google Meet. The learning process of reading class is conducted in the six meeting plus one of the assessing sections.

\section{Reading Skill}

Reading and listening are receptive skills. Receptive skills are the ways in which people extract meaning from the discourse they see or hear (Harmer, 2007:199). Especially for reading, this skill is receptive because one who is active in reading the text but the text is written by other person. However, one must have some aspects to understand the text. The aspects are background knowledge and reading technique. The importance for background knowledge in reading skill is to fasten the comprehension process. A student who doesn't know about technical term for example, he will find difficulties in reading an engineering text. The English teacher should include the background knowledge and reading technique in her/his class. The two can be integrated into the teaching of reading. 
Moreover, Reading is one of the four language skills that could construct one's mind. It is safe to say that reading is a crucial skill to have good communication skill as it could give background knowledge for the speakers. However, reading is not like listening. It is a skill which the learner must be active. The students must read the various texts and be able to apply the reading technique to understand the content of the reading texts. According to McLaughlin in Celce-Murcia (2001) reading is the most complex and difficult skill that students should master at school. The complexity of reading is including the students' interest on reading, the texts genre, and the level of reading text. It is complex because those aspects should be considered by the teacher.

Reading itself has many purposes. As stated by Reading serves specific purposes (Grabe and Stoller, 2002). For example:

- Reading to find specific information. This is called scanning. Readers try to find out about a specific word or piece of information.

- Reading to skim the text. This is done to get a general understanding of the text.

- Reading to learn from texts. It occurs in an academic context where the reader has to memorize information and details.

- Reading to integrate information. The reader decides on which information to use in order to write and critically analyze the contents. 
The purposes in the previous paragraph are the guide for the teacher in arranging proper teaching process for the students. The purposes of reading above influence the teacher much in deciding the objective of reading comprehension class. The teacher does not teach only the type of the text but also the strategy of how to understand the text. The two are the basic in comprehending the text so a reading class should cover the both. How to deliver the two in a class must be planned well by the teacher. She/he must prepare specific plan for reading section for this.

The purposes above are driven the teacher to decide what the proper instructions in online learning process. The instructions are no different from offline learning. The different is the way of manage the student in doing the instructions. The instructions and the activities after them are arranged in the instructional design below:

Table 1. The Instructional Design on Reading Online Teaching

\begin{tabular}{|l|l|l|l|}
\hline No & Purpose & Instructions & After the Instructions \\
\hline 1. & $\begin{array}{l}\text { Reading to find } \\
\text { specific } \\
\text { information }\end{array}$ & $\begin{array}{l}\text { a. Where is the } \\
\text { subjects/objects of the } \\
\text { text? } \\
\text { b. How can a person } \\
\text { contact } \\
\text { subjects/objects? the asks one } \\
\text { c. And two students to } \\
\text { questions using W/H } \\
\text { questions } \\
\text { answer the questions } \\
\text { and allow other } \\
\text { students to answer if } \\
\text { they have different } \\
\text { answers. }\end{array}$ \\
\hline 2 & $\begin{array}{l}\text { Reading to skim the } \\
\text { text }\end{array}$ & $\begin{array}{l}\text { What is the main } \\
\text { idea of the first, second, }\end{array}$ & $\begin{array}{l}\text { The teacher allows } \\
\text { the students who }\end{array}$ \\
\hline
\end{tabular}




\begin{tabular}{|c|c|c|c|}
\hline & & etc paragraph? & $\begin{array}{l}\text { know the main idea } \\
\text { to speak up. }\end{array}$ \\
\hline 3 & $\begin{array}{l}\text { Reading to learn from } \\
\text { text }\end{array}$ & $\begin{array}{l}\text { a. What can you infer } \\
\text { from the paragraph .. ? } \\
\text { b. What can you take } \\
\text { from the text...? }\end{array}$ & $\begin{array}{l}\text { The teacher leads a } \\
\text { discussion about the } \\
\text { whole content of the } \\
\text { text. }\end{array}$ \\
\hline 4 & $\begin{array}{l}\text { Reading to integrate } \\
\text { the information }\end{array}$ & $\begin{array}{l}\text { a. Do you have any } \\
\text { opinion about the subject } \\
\text { of the text? } \\
\text { b. Can you give other } \\
\text { example to continue the } \\
\text { paragraph? }\end{array}$ & $\begin{array}{l}\text { The teacher drives } \\
\text { the students to } \\
\text { discuss about other } \\
\text { things which have the } \\
\text { similarity with the } \\
\text { content f the text. }\end{array}$ \\
\hline
\end{tabular}

\section{The Assessment on Reading Skill}

The process of the e-learning in this research is ended in by an evaluation test. The test is conducted in the seventh meeting. The teacher is full responsibly to the materials and the problems in the assessment. Furthermore, he must do the scoring process. He checks the answer as well as gives notes to the students' error in answers. This assessment is hoped could inform the students' weakness in reading and the teacher is responsible to give important feedback to the students how to fix them. In other side, the teacher must arrange a non-intimidating evaluation test.

\section{Classroom-Based Reading Assessment (CBRA)}

The classroom-based reading assessment is the most proper type of assessment for the research. The class is not connected with the school materials or competence target from the school. The class has its own target which makes the teacher has more freedom in choosing the materials and assessment arrangement. The 
target of six meeting reading class is to improve students' skill in reading short texts consist of 8 to 15 sentences. The classroom-based Reading assessment in these contexts is primarily used to measure student learning and presumably to improve student learning (Grabe and Jiang, 2014). The components measured in this assessment are:

1. Passage reading fluency and reading rate,

2. Automaticity and rapid word recognition,

3. Search processes,

4. Morphological knowledge,

5. Text structure awareness and discourse organization,

6. Strategic processing abilities,

7. Summarization abilities (and paraphrasing),

8. Complex evaluation and critical reading.

The result of the assessment itself is not the final to judge the reading skill of the students. The result of CBRA for the class as stated by Black and Wiliam cited by Grabe and Jian (2015) is to give The critical goal of this assessment approach is to provide immediate feedback on tasks and to teach students to engage in more effective learning instead of evaluation of their performance. An important element of assessment for learning is the follow-up feedback and interaction between the teacher and the students. 


\section{The Benefit of Teaching Small Class}

The traditional class with the big numbers of students may be not as effective as the small class. How about the online class with $30-40$ students? The teacher may find a difficult situation when the students don't blend with the class maximally. A small class may be the best option for online learning. The followings are the benefit of small class based on Kennedy (2018):

1. There's nowhere to hide in the small class

All the members of the class get noticed in the same way. The students also have the same opportunity to express their opinion and to participate actively in discussion. The small class also makes students know each other better and could avoid feeling ashamed.

2. Teacher can actually teach when the classes are small

Teachers may more enjoy teaching small classes. It is difficult to find fit circumstances for teaching big classes. The small class is easy to monitor and teacher could more teaching. The teacher has more time to catch ideas, get more feedback, and have longer time to customize instruction and guidance.

3. The small class has social benefit.

The small class gives chance for students to know each other better then they will have more mutual interaction. They could work with peers without social barrier 
because the class is more being a community not a group of studying. Moreover, many studies found that the students from small class have better performances and higher grade in certain skill.

\section{The Previous Studies}

This research, for sure, is not the first which study about the reading class online. The similar researches about it had been conducted many times. As the online learning is relatively new for Indonesia teacher and students, the space for research on online learning is still wide open. This part discusses about the position of this research among three previous researches below:

The first study was work of Harits Setyawan in 2019. This study aimed at investigating the effect of Blended Method (online and offline teaching and learning) and Traditional Method (offline teaching and learning), as the comparison, on students' reading achievement. There were 200 college students involved in this study. Half of them were taught through a blended teaching method and half of them were taught through a traditional teaching method. The data were taken from the students' final scores in the lectures which included scores of assignment, quiz, midterm test, and final term test. The final scores of the two groups were compared to find out the effect of the blended teaching method and the traditional teaching method. The result showed that the scores of students who were taught through Blended Method were significantly better than the scores of students who were taught through Traditional Method. It indicates that utilizing new methods while 
maintaining good aspects of pre-existing methods has a positive impact on students' achievement.

The second research was conducted by Ayu Istiana Sari et.al in 2019. This research aims to determine the design of smart phone learning application-android based to the 10th grade of Senior High Schools in Solo, Central Java Indonesia for teaching reading comprehension. In this research, the researcher used ADDIE (Analysis-Design-Develop-Implement-Evaluate) as the instructional design. In this study, there were four experts who validated the android -based learning application. They were, two material experts and two digital learning media experts. The result showed that smartphone learning application-android based is feasible to use. This takes into consideration the assessment of the expert team, both material and media that provide an assessment in the excellent category. Thus, it can be concluded that the developed media is feasible for production and tested in the next stage.

The third previous study is the work of Yusup Supriyono in 2018. This research is aimed at exploring reading learning performed by English foreign language learners when Web based instruction is integrated into reading classroom. Teaching learning activity follows the steps: orientation, discussion, material exploration, action, test, and reflection. Two data collecting methods-journal and interview are administered to three students of the fourth semester of English Department in University of Siliwangi Tasikmalaya Indonesia after the selected individuals finished the reading course for one semester. The findings show that the 
teaching learning process using Web based instruction enlarges the students' reading activity, enhances micro and macro reading competences, and builds affection.

\section{Method}

The research is designed as a descriptive qualitative study. As stated by Gay, Mills and Arasian (2006) that qualitative methodology allows researcher to focus on perceptions, behaviors and experiences. This study describes the instructional design in teaching reading online to the small class. The data gathered from the six meeting of online learning and one progress test after the six meetings.

The subjects of this research are 5 students with pre-intermediate level of English skill. Their age are in the range of $16-18$ and have been studying English for a year under the guidance of the researcher. They are experienced 6 online meetings and each meeting's duration is maximum 75 minutes.

The instruments used to get the data are set under the research questions: 1) What the instructional design applied by the teacher in teaching reading to the small class?, 2) Is the instructional design effective to increase the students' reading comprehension?. The instruments are:

\section{Observation Sheets:}

The writer made the observations using sheets prepared with a list of observation guides. The researcher observes the whole process of the teaching from the teaching plan to the process of evaluating the progress test. All the activities dealing with the learning process are observed and noted. 


\section{Documentation}

Documentation included the lesson plans and the texts, a list of worksheets from the students and the result of progress test. The documentation is purposed to see clearly and understand the phenomena and conditions in the classes studied.

The data analyzed under the principle of qualitative - narrative technique without any statistical analysis. The researcher refers the data analysis steps from Biklen and Bogdan (1992) which stated that data analysis is the process of systematically searching through and arranging interview transcripts, field notes and other materials in order to understand and present them.

\section{Results and Discussion}

The class is active in the first meeting because the students have already met with the teacher in the traditional class. So they could skip the introduction section. The students are directed to the new way of learning English. The teacher has prepared the teaching plan for the six meeting at once. The plan is including the texts, the instructions and the assignment in the end of each meeting. The followings are the result of the six meetings conducted with complete teaching plan: 


\section{The Teaching Plan}

Class

Number of Students

Learning Target
Pre - intermediate

5

Able to comprehend simple texts with various genres

\begin{tabular}{|c|c|c|c|}
\hline No & Genre & Date / time & Online media \\
\hline 1. & $\begin{array}{l}\text { Descriptive text: } \\
\text { Ijen Boulevard } \\
\text { Taken From: } \\
\text { https://www.kampongtourist.com/index.php } \\
\text { /sightseeing-malang/ijen-boulevard-malang) }\end{array}$ & $\begin{array}{l}\text { August 8, } 2020 \\
19.30-20-45\end{array}$ & $\begin{array}{l}\text { Google Meet and } \\
\text { WA group }\end{array}$ \\
\hline 2. & $\begin{array}{l}\text { Report Text: } \\
\text { What is a Hybrid? } \\
\text { Taken from } \\
\text { https://www.caranddriver.com/features/ } \\
\text { a26390899/what-is-hybrid-car/ }\end{array}$ & $\begin{array}{l}\text { August } 14, \\
2020 / \\
19.30-20-45\end{array}$ & $\begin{array}{l}\text { Google Meet and } \\
\text { WA group }\end{array}$ \\
\hline 3. & $\begin{array}{l}\text { Narrative text: } \\
\text { The Dinosaur Dig } \\
\text { Taken from: } \\
\text { https://learnenglishkids.britishcouncil.o } \\
\text { rg/sites/kids/files/attachment/short- } \\
\text { stories-dinosaur-dig-transcript.pdf }\end{array}$ & $\begin{array}{l}\text { August } 18, \\
2020 / 19.30-20 \\
-45\end{array}$ & $\begin{array}{l}\text { Google Meet and } \\
\text { WA group }\end{array}$ \\
\hline 4. & $\begin{array}{l}\text { Recount text: } \\
\text { The Best Meal so Far } \\
\text { Taken from: } \\
\text { https://uxdesign.cc/what-do-we- } \\
\text { talk-about-when-we-talk-about- } \\
\text { experience-999c13ecda88) }\end{array}$ & \begin{tabular}{l}
\multicolumn{1}{c}{ August 22,} \\
$2020 / 19.30-20$ \\
-45
\end{tabular} & $\begin{array}{l}\text { Google Meet and } \\
\text { WA group }\end{array}$ \\
\hline 5. & $\begin{array}{l}\text { Explanation Text: } \\
\text { Digital Television and Radio } \\
\text { taken from: } \\
\text { https://www.sciencedirect.com/topi } \\
\text { cs/engineering/digital-television }\end{array}$ & $\begin{array}{l}\text { August } \quad 26, \\
2020 / 19.30-20 \\
-45\end{array}$ & $\begin{array}{l}\text { Google Meet and } \\
\text { WA group }\end{array}$ \\
\hline & $\begin{array}{l}\text { Hortatory Exposition } \\
\text { E-Commerce for Business: } \\
\text { The Good and the Bad Side } \\
\text { Taken from: } \\
\text { http://eyesimple.us/blog/e- } \\
\text { commerce-for-business-good-or-bad/ }\end{array}$ & \begin{tabular}{l}
\multicolumn{1}{c}{ August $\quad 30}$, \\
$2020 / 19.30-20$ \\
-45
\end{tabular} & $\begin{array}{l}\text { Google Meet and } \\
\text { WA group }\end{array}$ \\
\hline
\end{tabular}


The Teaching Arrangement:

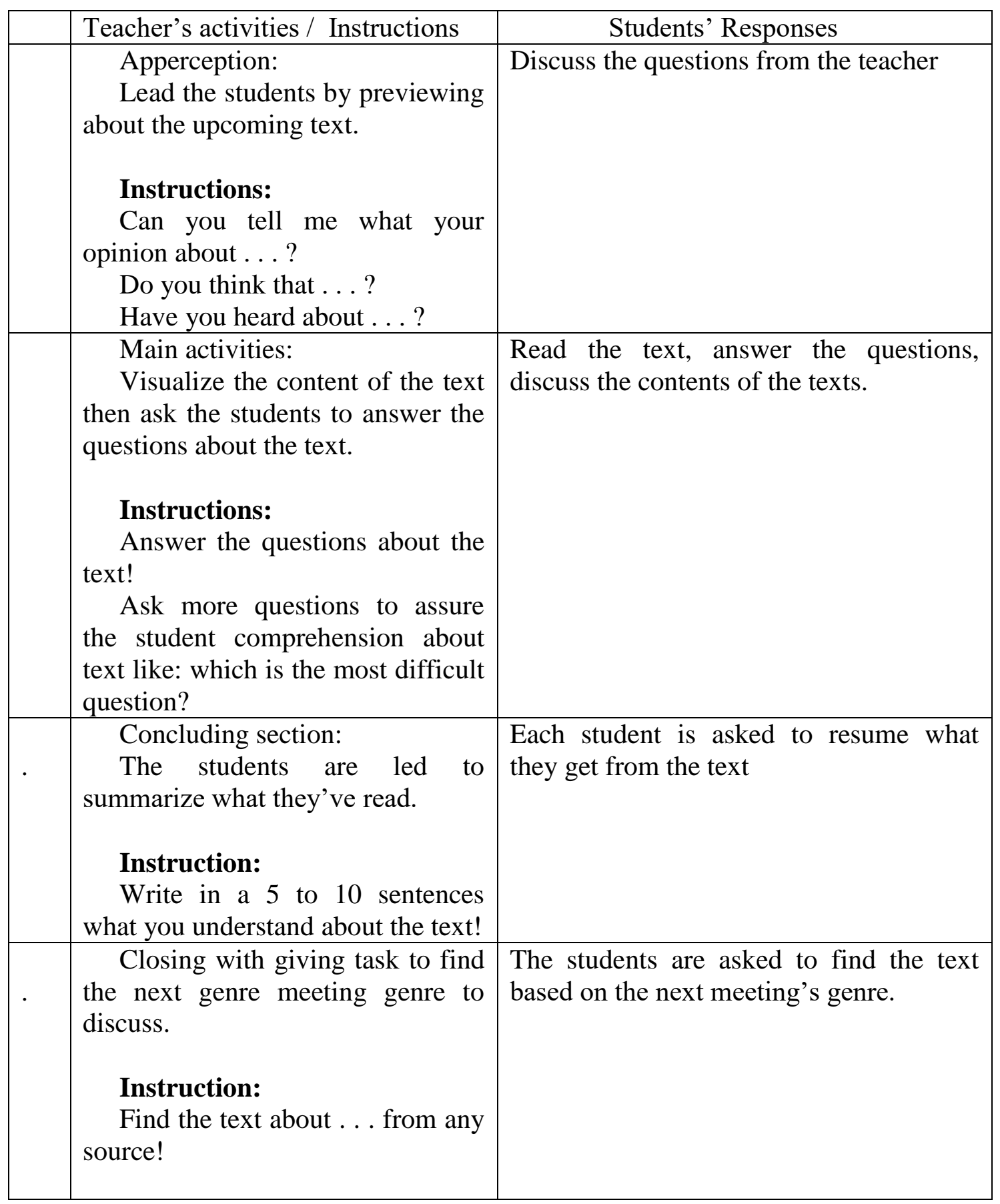


Table 2, the Progress Test Result

\begin{tabular}{|l|l|l|l|}
\hline No & Students & Score & Description \\
\hline 1. & AK & 2 & $\begin{array}{c}\text { Can understand the content of the text, read the } \\
\text { text effectively and able to find the keywords of } \\
\text { the simple texts }\end{array}$ \\
\hline 2. & DK & 6 & $\begin{array}{c}\text { Can understand the content of the text, and } \\
\text { able to find the keywords of the simple texts }\end{array}$ \\
\hline 3. & Er & 8 & Can understand the content of the simple text \\
\hline 4. & GP & 0 & $\begin{array}{c}\text { Can understand the content of the text, and } \\
\text { able to find the keywords of the simple texts. }\end{array}$ \\
\hline 5. & NAG & 0 & $\begin{array}{c}\text { Can understand the content of the text, and } \\
\text { able to find the keywords of the simple texts }\end{array}$ \\
\hline
\end{tabular}

Teaching students online is new for English teacher, especially for the researcher. The teacher and the students are used to with the traditional class and the direct interaction in the class. But the online learning, as the new way of learning, put the teachers and the students in an adaptation phase. Fortunately, the teacher and the students have already got used to with digital devices like laptop and smart phone. The adaptation is more in function of the online media like Google Meet and WhatApps Group (WAG). In flash, the internet could break the space and luckily, the teacher and the students are in the location where the internet signal is good. So, the teacher and the students just need to be more discipline with the schedule.

The adaptation is in moving the classroom to the virtual class. The teacher plays the same role as the traditional but in the different setting so do the students. All learning process and instructions are the same as the offline meeting. The teacher 
leads the process as the prepared plan. As the students are only five, the instructions can be delivered well and the students could do the instructions.

The first meeting was the key of the adaptation. This meeting seems like a trial for a class. The teacher and the students spent almost 10 minutes just for checking the visual and the sound of the Google Meet. Then, the class could work as the plan. The teacher started by doing apperception like asking about the iconic places in the city then asked them to make comparison from the placed their mentioned (the teacher asked them to mention different places). Each student had to respond and speak up at least once in every instruction. The Instructions covered how to scan, skim, memorize, and integrate as the followings: (1) Mention the words do you think could present the text? (2) What is the main idea of the text? (3) Answer the question below the text! (4) Can you mention the same things as you find in the text?

The next meetings ran better because the teacher and students had evaluated the process of in the first meeting. The teacher asked the students to be ready at least 15 minutes before the learning process. The class was run as the teaching plan and some meetings ran overtime. The most dominant activity was the discussion when the students expressed their opinions about what they comprehended about the texts, sometimes the class morphed into speaking class. The teacher changed the role when it happened to be a leader of the class in order to make the class conducive. The assignments for finding text with same genre for the text meeting were done completely by the students. This became a half success of the next meeting. However, the number of students was the most important aspect which supported class as plan. 
The small numbers of students may give many advantages in the online class. First, the teacher could be able to do "surveillance" maximally because each student could be seen clearly on the screen of Google Meet. In the other hand, the student had the same opportunity to be active. They got the same texts and the same serial of instructions. Moreover, the levels of the texts were still on their reach so a short apperception was proper to lead the students on track. The section of question and answer were also done maximally as each student at least asked one question in this section. For short, the number of students in the age of $16-18$ supports the instructional design in the class.

There are three previous researches compared with the recent research to compare. Firstly, the research's result is in line with the result of Harits' work. Both researchers found that the online instructions didn't give significant different for students. Moreover, the comparison in Harit's work showed students who studied with online instructions got higher score in the evaluation test. These similarities indicate that students' adaptation to the online learning is very fast as they hold the gadget almost all the time. The second research by Ayu Istiana Sari et.al found the instruction design in Android could be a good choice for the millennial students because it is user-friendly and what needed for online learning are available. Both researchers also found that discipline is the key in online learning. The notification in android could be a good reminder for teacher and students. The last is Supriyono's work. This research found that web-based instructions could enlarge students' options in adding their reference on texts. The similarities are in instruction maximizing. 


\section{Conclusion}

Teaching reading online is new for the teacher and students. This is about to move the classroom to online class. Luckily, the researchers had a chance to trial an instructional design trough an online class with 5 students so he moves the traditional class to online via Google Meet and WAG. In this research, Google Meet was used as the media to discuss the text while WAG was the media to share various texts. The instructional design was executed as the plan and the students got maximal result from the learning process. The number of the students influenced much in the teaching process because the chances to answer the questions and to express opinion were spread evenly. Moreover, the numbers of students offers ideal "surveillance" for teacher.

The researcher could suggest two things after. First, online learning will be a new way of teaching sooner or later and the pandemic makes it comes faster. The teachers are pushed to design a traditional class room atmosphere. The instructional design tested in this research hoped could be one of the useful references for the English teachers. Second, this research was only focus on the small class. Different result may be gained in the bigger class. This different point is researchable.

\section{About the Writer}

Yopi Arianto is currently teaching at Kahuripan University of Kediri. His main research interests are in English for Specific Purposes (ESP) and English for Academic Purposes (EAP). He can be reached at Yopiarianto81@ gmail.com. 


\section{Reference}

Biklen, S., \& Bogdan, R. C. (1992). Qualitative Research for Education: An Introduction to Theory and Method. London: British Library.

Celce-Murcia, Mariane. 2001. Teaching English as a Second of Foreign Language. 3rdedition. Boston: Heinle\& heinle Publishers.

Clover, Isabelle, 2017, Advantages and Disadvantages of $e$ - Learning, https://elearningindustry.com/advantages-and-disadvantages-of-elearning retrieved: September 10, 2020

Gay, L. R., Mills, G. E., \& Arasian, P. (2006). Educational Research:Competencies for Analysis and Application, 8th ed. Upper Saddle River, NJ: Prentice Hall.

Grabe, W., \& Stoller, F. (2011). Teaching and Researching Reading (2nd ed.). Routledge.

Grabe, W., \& Jiang, Xiangying, 2014, The Companion to Language Assessment, First Edition. Edited by Antony John Kunnan. John Wiley \& Sons, Inc. Published 2014 by John Wiley \& Sons, Inc. DOI: 10.1002/9781118411360.wbcla060

Harmer, Jeremy. 2007. The Practice of English Language Teaching. United Kingdom: Pearson Education Limited.

Kennedy, Robert. 2018, Why Small Class Sizes Work, https://www.boardingschoolreview.com/blog/why-small-class-sizes-work Retrieved: September 10, 2010

Merrill, M. D.; Drake, L.; Lacy, M. J.; Pratt, J. (1996). "Reclaiming Instructional Design" (PDF). Educational Technology

Sari, Ayu Istiana.,Suryani, Nunuk., Rochsantiningsih, Dewi., Suharno. 2019. The Development of Android-Based Smartphone Learning Application on Teaching Reading Comprehension. AIP Conference Proceedings 2194, 020112; https://doi.org/10.1063/1.5139844 , 1 - 7

Sener, John, 2015. Updated E-Learning Definition, https://onlinelearningconsortium.org/updated-e-learning-definitions-2/

Retrieved: September 10, 2020. 
Setywan, Harits. 2019. Blended Method: Online-Offline Teaching And Learning, On Students' Reading Achievement. English Education: Jurnal Tadris Bahasa Inggris pISSN 2086-6003 | eISSN 2580-1449 Vol 12 (1), 22-33

Supriyono, yusup. 2018. EFL Learners' Reading Learning In Web Based Instruction Setting. Edulite: Journal of English Education, Literature and Culture. Vol 3 No 1, 91 $-100$

Tamm, Sander, 2019. What is E-learning? Defining what is e-learning is not as easy as it might first appear. https://e-student.org/what-is-e-learning/ retrieved: September 10, 2020 